\title{
Opieka nad dzieckiem ze schizofrenią paranoidalną oraz padaczką w szkole - studium przypadku
}

\author{
Care-taking of the Paranoid Schizophrenia and Epilepsy Suffering Children in School \\ Environment - Case Study
}

\section{Streszczenie}

Wstęp. Schizofrenia jest chorobą, która stanowi duże wyzwanie dla psychiatrii. Do dnia dzisiejszego trudno określić jednoznacznie etiopatogenezę tej choroby u osób dorosłych, jak i również u dzieci. Padaczka jest chorobą neurologiczną, najczęstszą wieku dziecięcego, bo aż w 75 \% początek tej choroby przypada na okres do 19 roku życia. Bardzo często występuje już w pierwszym okresie życia.

Cel. Celem pracy jest przedstawienie opieki nad dzieckiem ze schizofrenią paranoidalną oraz padaczką w szkole oraz ukazanie sposobów umiejętnego radzenia sobie $\mathrm{z}$ trudnościami napotykanymi u dzieci z zaburzeniami psychicznymi.

Prezentacja przypadku. Chłopiec, lat 12, data urodzenia 28 kwietnia 2004 roku. Rozpoznanie schizofrenia paranoidalna oraz padaczka. Leczony od 2013 roku. Pierwsze objawy niepokojące występujące u chłopca, pod względem zachowania zaobserwowano w 2013 roku. Stan zdrowia chłopca znacznie utrudnia uczęszczanie do szkoły, uczeń może brać udział $w$ obowiązkowych zajęciach edukacyjnych organizowanych $\mathrm{z}$ oddziałem $\mathrm{w}$ szkole lub indywidualne $\mathrm{w}$ odrębnym pomieszczeniu w szkole.

Dyskusja. Przyczyny schizofrenii u dzieci są złożone. Do zachorowania może dojść w wyniku wspólnego działania biologicznych czynników jak: zmian zachodzących wbudowie anatomicznej mózgu czy nieprawidłowego działania neuroprzekaźników, genetycznych czynników, które zwiększają ryzyko zachorowania w momencie gdy na schizofrenię choruje członek rodziny bądź bliski krewny, a także czynniki psychogenne oraz środowiskowe. Podstawową metodą leczenia schizofrenii występującej u dzieci jest zastosowanie leków, a także oddziaływań terapeutycznych.

Wnioski. Dzieci chore na schizofrenię i padaczkę w okresie szkolnym są narażone na wykluczenie społeczne, ze względu na odmienność $\mathrm{w}$ swoim zachowaniu. Dzieci z zaburzeniami psychicznymi niejednokrotnie są izolowane przez rodziców, co potęguję ich stany napięcia, lęki. Rodzice przezywają silny stres z chorobą dziecka. Dużą rolę w rozumieniu problemu i uświadomieniu rodziców o problemach ich dzieci stanowią poradnie psychologiczno-pedagogiczne oraz psycholog lub pedagog szkolny, a także nauczyciele współpracujący bezpośrednio z chorymi dziećmi.

\footnotetext{
Abstract:

Introduction. Schizophrenia is a brain disorder that poses a great challenge for modern psychiatry. It is still very difficult to clearly identify the etiopathogenesis of this illness in case of both adults and children.
} 
Epilepsy comes as the neurological disorder of childhood and adolescence stage as its onset starts not later than till the age of 19; it also quite often occurs in the first period of human's life.

Aim. This paper aims to present various methods of care-taking of children with paranoid schizophrenia and epilepsy in their school environment, and provide methods for successful coping with any difficulties encountered in case of mentally ill children.

Case presentation. A twelve-year boy born on 28 July 2004 diagnosed with paranoid schizophrenia and epilepsy. The treatment started in 2013 when first disturbing symptoms were noticed. His health problems make it extremely difficult for him to attend school. He can take part in regular classes or individual classes in a separate room.

Discussion. The causes of schizophrenia among children are very complex. The illness may be triggered by biological factors, for example changes occurring in the brain or abnormal activity of neurotransmitters; genetic factors, especially when a member of the family or a close relative suffered from the illness; but also community factors are crucial..The primary method for treating schizophrenia, occurring in children, is the use of drugs and therapeutic interactions.

Conclusions. Children with schizophrenia or epilepsy are susceptible to social exclusion due to their behaviour differences. It most often happens that the children suffering from psychical disorders are isolated by their parents which triggers their anxiety and fears. The parents undergo severe stress referring to the child's illness. Psychological and pedagogical counselling centres, the school-based psychologists or pedagogy therapists, as well as teachers cooperating directly with the ill children play a vital role in assisting the parents in understanding the problem and coping with it.

Słowa kluczowe: schizofrenia, padaczka, opieka nad dzieckiem, szkoła.

Key words: schizophrenia, epilepsy, childcare, school.

\section{Wstęp}

Schizofrenia jest chorobą psychiczną. Bleuer po raz pierwszy użyl terminu schizofrenia w 1911 roku. Słowo schizofrenia oznacza "rozszczepienie rozumu lub serca" (schizo rozszczepiam, phren - rozum, serce). Schizofrenia jest chorobą, która stanowi duże wyzwanie dla psychiatrii. Do dnia dzisiejszego trudno określić jednoznacznie etiopatogenezę tej choroby u osób dorosłych, jak i również u dzieci. Pierwsze objawy schizofrenii pojawiają się przed 15 rokiem życia u około $4 \%$ chorych, tylko $1 \%$ przed 10 rokiem życia, natomiast największy procent zachorowania na schizofrenię pojawia się przed 20 rokiem życia i stanowi $12-35 \%$. Na schizofrenię w okresie dzieciństwa chorują częściej chłopcy niż dziewczynki. Przewaga ta jest zauważalna $\mathrm{w}$ okresie dzieciństwa, natomiast tendencję malejącą zauważa się $\mathrm{w}$ okresie dojrzewania. W okresie dorosłości zachorowalność na schizofrenię charakteryzuję się zbliżoną tendencją zarówno u mężczyzn jak i u kobiet [1,2].

Zgodnie z definicją Światowej Organizacji Zdrowia termin padaczka oznacza przewlekle zaburzenia czynności mózgu o różnej etiologii, które cechują się nawracającymi napadami. Padaczka nie jest uważana za chorobę psychiczną, czasami jednak może prowadzić do obniżenia sprawności intelektualnej. Padaczka jest chorobą neurologiczną, najczęstszą wieku dziecięcego, bo aż w 75 \% początek tej choroby przypada na okres do 19 roku życia. Bardzo często występuje już w pierwszym okresie życia. U dzieci napady padaczkowe występują bardzo często u około $30 \%$ przypadków napady padaczki występują już przed 4 rokiem życia dziecka, w $50 \%$ przypadków napady pojawiają się przed 10 rokiem życia, a w $70 \%$ przypadkach przed ukończeniem 15 roku życia [3,4].

Dzieci, które chorują na schizofrenię i padaczkę w okresie szkolnym pomimo trudności, jakie napotykają ze strony choroby, jej rozwoju oraz przebiegu, muszą zmagać się również z edukacją szkolną oraz opinią społeczną. 
Celem pracy jest przedstawienie opieki nad dzieckiem ze schizofrenią paranoidalną oraz padaczką $\mathrm{w}$ szkole oraz ukazanie sposobów umiejętnego radzenia sobie z trudnościami napotykanymi u dzieci z zaburzeniami psychicznymi.

\section{Prezentacja przypadku}

Chłopiec, lat 12, data urodzenia 28 kwietnia 2004 roku. Rozpoznanie schizofrenia paranoidalna oraz padaczka. Leczony od 2013 roku. Pierwsze objawy niepokojące występujące u chłopca, pod względem zachowania zaobserwowano w 2013 roku. Badanie elektroencefalograficzne po raz pierwszy u dziecka wykonano 15 stycznia 2015 roku w wieku 8 lat 5 miesięcy chłopca. Rozpoznano u chłopca zaburzenia zachowania. Badanie wykonane było w czuwaniu. Zapis zróżnicowany przestrzennie, asymetryczny, z przewagą amplitudy po stronie prawej. Czynność podstawową w okolicy ciemieniowo-potylicznej stanowią fale alfa o częstotliwości 9-10 Hz i amplitudzie od $60 \mathrm{uV}$ po stronie lewej, do $100 \mathrm{uV}$ po stronie prawej. W okolicy czołowej rejestruje się czynność beta, współwystępująca z falami alfa i theta. Reakcja OZ wyrażona. Na tym tle w okolicy skroniowo- ciemieniowo-potylicznej, z przewagą po stronie prawej w sposób ciągły rejestrują się odcinki fal o częstotliwości $9.8 \mathrm{~Hz}$ i amplitudzie od 130 do $244 \mathrm{uV}$. U dziecka zalecono wykonanie badania EEG podczas snu. Dnia 17 kwietnia 2013 roku u dziecka zgodnie $\mathrm{z}$ zaleceniami wykonano badanie EEG podczas snu. U chłopca wieku 8 lat 8 miesięcy rozpoznano stany napadowe oraz schizofrenię. Zastosowano leczenie farmakologiczne. Badanie EEG wykonano podczas snu. W okresie senności zarejestrowano rozpad czynności podstawowej, pojawiły się ostre fale wierzchołkowe. Wrzeciona snu podczas snu lekkiego rejestruje się w postaci fal o częstotliwości $12 \mathrm{~Hz}$ i amplitudzie $50 \mathrm{uV}$. Podczas budzenia rejestrowały się typer synchroniczne budzenia. U chłopca orzeczono w wyniku badania zapis snu nieprawidłowy, ze zmianami zlokalizowanymi w okolicach czołowych o charakterze napadowym i tendencji do uogólniania. W 2015 roku chłopiec otrzymuje wydane przez Powiatowy Zespół do Spraw Orzekania o Niepełnosprawności orzeczenie o niepełnosprawności 02-P ( choroby psychiczne). Niepełnosprawność datuję się od siódmego roku życia. Zgodnie z przeprowadzonym badaniem, wywiadem oraz $\mathrm{z}$ treści dokumentacji medycznej u chłopca orzeczono, iż ma naruszoną sprawność organizmu. Wymaga korzystania $\mathrm{z}$ systemu środowiskowego wsparcia w samodzielnej egzystencji, opieki i pomocy innej osoby oraz stałego współudziału na co dzień opiekuna w procesie leczenia, rehabilitacji i edukacji, jak i również konieczność stałej lub długotrwałej opieki lub pomocy innej osoby w związku ze znacznie ograniczoną możliwością samodzielnej egzystencji. W wieku 11 lat u chłopca wykonywane jest kolejne badanie elektroencefalograficzne. Badanie wykonywane $\mathrm{w}$ czuwaniu. Zapis czuwania u chłopca nieprawidłowy, ze zmianami napadowymi o charakterze ciągłym, zlokalizowanymi w okolicach centralno-skroniowo-potylicznych z tendencja do uogólniania. Oprócz zaburzeń zachowania u chłopca pojawiają się coraz większe trudności z edukacją szkolną oraz klimatyzacją chłopca w środowisku szkolnym. Chłopiec poprze swoje zachowania nieadekwatne do sytuacji, nadpobudliwość oraz rozdrażnienie ma problem z adaptacją w szkole. Występują konflikty miedzy chłopcem, a resztą środowiska szkolnego. W 2015 roku Zespół Orzekający Poradni Psychologiczno-Pedagogicznej orzekł o potrzebie indywidualnego nauczania chłopca. Chłopiec badany w poradni po raz drugi. Pierwsze badanie odbyło się w 2012 roku, kiedy chłopiec uczęszczał do klasy drugiej szkoły podstawowej. W diagnozie zespół przedstawił informacje o możliwościach rozwojowych i potencjale ucznia. Dziecko ma roczne opóźnienie organizacyjne. Od stycznia 2013 roku uczestniczy w zajęciach socjoterapeutycznych organizowanych na terenie poradni. Ze względu na problemy zdrowotne od kwietnia 2013 roku realizuje obowiązek szkolny w formie indywidualnego nauczania. Wynik badania psychologicznego przeprowadzony 
w 2015 roku wskazuje na regres w ogólnym rozwoju umysłowym dziecka, który przebiega aktualnie na poziomie upośledzenia umysłowego w stopniu lekkim względem jego grupy rówieśniczej, w sposób nieharmonijny. Obserwuję się zaburzenia i opóźnienia rozwojowe, które wyraźnie pogłębiły się w odniesieniu do badania poprzedniego z 2012 roku. Deficyty poznawcze ujawniają funkcje słowno-pojęciowe, jak i sfera wykonawcza. Wzbogacenia i uzupełnienia wymaga znajomość norm i zasad społecznych, gdyż chłopiec miał duże problemy z dokonaniem właściwej oceny i analizy prezentowanych zjawisk i sytuacji społecznych oraz wskazaniem odpowiedniej formy reagowania na nie. Poważne deficyty ujawnia także słownictwo jakim dysponuje chłopiec, nie potrafi skutecznie poradzić sobie z definiowaniem prostych pojęć, a jego wypowiedzi były ubogie. Kontakt niewerbalny w dalszym ciągu przebiega nieprawidłowo, chłopiec wykazuje duże trudności z jego nawiązaniem. Bardzo ubogi jest zasób ogólnych wiadomości i informacji o otaczającym świecie zdobywanych w toku edukacji i doświadczeń własnych. Powyższe uległy dużemu pogorszeniu, relatywnie do badania poprzedniego i stanowią słabą stronę w intelekcie chłopca. Świadczyć też mogą o problemach w obrębie pamięci długotrwałej, dlatego chłopiec powinien stosować większą ilość powtórzeń przyswajanego materiału w różnych formach i kontekstach. Poważne problemy wskazują także ujęte $\mathrm{w}$ badaniu formy myślenia, które odgrywają ważną rolę $\mathrm{w}$ procesie edukacji, to jest: wnioskowanie przyczynowo-skutkowe oraz rozumowanie matematyczne. Wyraźne korzystniej prezentuje się abstrakcyjne myślenia logiczne (porównywanie, klasyfikowanie, uogólnienie), które rozwinięte jest na poziomie zgodnym z oczekiwaniami dla wieku metrykalnego chłopca. Bardzo wolne jest tempo przyswajania prostego materiału symbolicznego w oparciu o skojarzenia wzrokowo-ruchowe oraz tempo pracy graficznej. Percepcja wzrokowa, analiza i synteza wzrokowa oraz pamięć wzrokowa prezentują się zadowalająco stanowiąc mocne ogniwo $\mathrm{w}$ intelekcie chłopca, na którym warto się oprzeć $\mathrm{w}$ przyswajaniu wiadomości i umiejętności szkolnych. Duże kłopoty obserwuje się w obrębie ogólnej spostrzegawczości, chłopiec miał problemy, aby wskazać braki i błędy w materiale spostrzegawczym wzrokowo. Bardzo wąska jest pojemność pamięci słuchowej bezpośredniej. Obecnie przeprowadzone badanie pedagogiczne wskazuje na utrzymanie się trudności $\mathrm{w}$ nabywaniu bieżących wiadomości i umiejętności programowych. Występują poważne trudności w pisaniu. Chłopiec podjął próbę przepisywania tekstu drukowanego. Wykonywał to bardzo wolnym tempie, po jednej literce, mylił się i poprawiał. Zaniechano próby pisania z pamięci i ze słuchu ze względu na obserwowane nadmierne trudności. Poziom graficzny pisma jest niski-litery niekształtne, nie utrzymane $\mathrm{w}$ odpowiednich liniach. Chwyt narzędzia pisarskiego nieprawidłowy. Czyta po uprzednim głoskowaniu, poprawnie składa większość przeczytanych wyrazów. Częściowo rozumie wysłuchany tekst, nie zapamiętuje istotnych szczegółów. Dodaje i odejmuje w zakresie $100 \mathrm{w}$ pamięci, jednakże czasem wspiera się liczydłami. Nie podjął próby mnożenia liczb. Wykazał się bardzo słabym rozumieniem zadań tekstowych. Podczas badania chłopiec był mało zainteresowany zadaniami i pozytywnymi rezultatami swojej pracy. Zdarzało się, ze odmawiał wykonania jakiegoś zadania twierdząc " nie chce mi się". Jednakże chłopiec w końcu podejmował się wykonania poleceń i starał się doprowadzać do końca każde zadanie. Zalecenia jakie należy zastosować wobec ucznia to należy wskazywać warunki realizacji potrzeb edukacyjnych, a także możliwości uczestniczenia ucznia w życiu szkoły, formy stymulacji, rewalidacji, terapii, usprawnienia, rozwijania potencjalnych możliwości i mocnych stron dziecka oraz inne formy pomocy psychologiczno-pedagogicznej. W przypadku chłopca, którego stan zdrowia znacznie utrudnia uczęszczanie do szkoły, określa się zakres, w jakim uczeń może brać udział $\mathrm{w}$ obowiązkowych zajęciach edukacyjnych organizowanych z oddziałem w szkole lub indywidualne w odrębnym pomieszczeniu w szkole. Zaleceniem jest również włączenie chłopca 
do grupowych zajęć $\mathrm{w}$ szkole, zgodnie $\mathrm{z}$ zaleceniami lekarza. Ze względu na zaburzenia $\mathrm{w}$ funkcjonowaniu emocjonalnym $\mathrm{w}$ pracy $\mathrm{z}$ dzieckiem należy uwzględnić specjalne metody i organizację pracy, kontynuować zajęcia socjoterapeutyczne w poradni oraz kontynuować specjalistyczne leczenie. Z uwagi na utrzymujące się zaburzenia lękowe wynikające z przebiegu choroby chłopiec wymaga indywidualnej stałej opieki, dlatego też uzasadnione jest nauczanie indywidualne.

W 2016 roku wykonano kolejne badanie EEG w czuwaniu. Zapis zróżnicowany przestrzennie, asymetryczny z przewagą amplitudy po stronie lewej, modyfikowany artefaktami biologicznymi mrużenia oczu. Zapis czuwania z asymetryczna czynnością podstawową ze zmianami zlokalizowanymi wieloogniskowo o charakterze ciągłym i napadowym. W 2016 roku chłopiec znajduje się pod opieką lekarza psychiatry ze względu na stwierdzoną schizofrenię paranoidalną, padaczkę, której objawy okresowo nasilają się i upośledzają jego funkcjonowanie. Chłopiec został zbadany w poradni psychologiczno-pedagogicznej. Z opinii otrzymanej od nauczycieli ze szkoły chłopiec łatwo nawiązuje kontakt z nauczycielami uczącymi go. W czasie zajęć jest nadpobudliwy psychoruchowo. Często nie potrafi kontrolować swoich emocji. Zdarzają mu się napady złości oraz zachowania agresywne. Na uwagi reaguje niezadowoleniem, potrafi przerwać wykonaną pracę. Dziecko ma dość dobrą pamięć, stara się myśleć przyczynowoskutkowo. Chętnie wykonuje zdania, które są zgodne z jego zainteresowaniem. W przeciwnym wypadku wykazuje brak skupienia, niechęć, staje się niespokojny. Zespól Orzekający Poradni Psychologiczno - Pedagogicznej zaleca indywidualne nauczanie chłopca na kolejny rok w domu rodzinnym, zajęcia socjoterapeutyczne, porady i konsultacje oraz terapie psychologiczna w związku z opóźnieniami rozwojowymi dziecka oraz rozpoznanymi zaburzeniami określonych sfer funkcjonowania dziecka.

W czerwcu 2016 roku u dziecka wykonano kolejne badania EEG ze względu na nasilające się napady padaczkowe. W badaniu w lewym płacie ciemieniowym istocie białej zlokalizowano dwa drobne ogniska hiperintensywne. Cechy dyskretnej gliozy okołokomorowej, poza tym struktury mózgowia bez zmian ogniskowych. Układ komorowy symetryczny, bez przemieszczeń, nieposzerzony. W zatoce klinowej niewielkie pogrubienie śluzówki.

W dniu 22 czerwca 2016 roku chłopiec w wieku 12 lat trafia do oddziału psychiatrycznego w szpitalu. Chłopiec znajduję się pod stałą opieką psychiatryczną, leczony również z powodu padaczki. Ostatni napad padaczkowy nastąpił 3 miesiące temu. U dziecko nastąpiło pogorszenie stanu psychicznego objawiający się niespokojnym okresowo pobudzonymi agresjami w stosunku do domowników. Deklarował obecność doznań słuchowych i wzrokowych. Chłopiec wychowywany jest w rodzinie niepełnej. Ojciec dziecka nie żyje. Rodzina obciążona jest schizofrenią, ojciec dziecka również chorował na schizofrenie i był leczony farmakologicznie. Świadomość jasna oraz orientacja co do własnej osoby dziecka pełna, co do czasu niestety zaburzona. U chłopca w trakcie hospitalizacji w szpitalu psychiatrycznym występowały halucynacje wzrokowe, chłopiec wypowiadał urojenia ksobne, prześladowcze, wrogo nastawiony do najbliższych. Sen zaburzony. Przez większość pobytu na oddziale chłopiec prezentował postawę wycofania, izolującą, nie nawiązywał kontaktu wzrokowego. W trakcie pobytu wykonano badania obrazowe EEG oraz MRI głowy. Zmodyfikowano leczenie farmakologiczne uzyskując poprawę stanu psychicznego. W lipcu 2016 roku dziecko zostało wypisane do domu w stanie psychicznym stabilnym. Świadomość jasna, orientacja pełna. Tok myślenia z elementami nie do kojarzenia, bez objawów wytwórczych. U chłopca zastosowano włączenie nowych preparatów farmakologicznych. Matka oraz nauczyciele oceniają chłopca jako osobę bardzo ciepłą, choć bywają momenty stosowane przez chłopca zachowań agresywnych spowodowanych nasilaniem się objawów choroby. Chłopiec jest ufny wobec matki oraz 
nauczycieli z którymi pracuje. Matka chłopca jednak cierpi z powodu choroby chłopca, jak i również z jej zmienności. Matka ze względu na chorobę syna nie przyjmuje do końca wszystkich zaleceń zaleconych przez nauczycieli i pedagogów, co niejednokrotnie utrudnia pracę nauczycieli $\mathrm{z}$ chłopcem. Matka czasami prezentuję postawę osoby uzależnionej emocjonalnie psychicznie od chłopca, niejednokrotnie spełnia wszystkie polecenia chłopca. Wobec takiej postawy i uległości matki wobec chłopca, dziecko prezentuję postawę negatywną do współpracy z nauczycielami, którzy próbują oczekiwać od dziecka efektów z pracy edukacyjnej. Matka nie chętnie chcę integrować dziecko ze środowiskiem lokalnym, szkolnym, co powoduje, iż chłopiec zaczyna stawać się osobą bardziej zamkniętą w sobie oraz nieufną wobec nowych osób. Izolacja chłopca wobec środowiska szkolnego negatywnie wpływa na rozwój chłopca. W 2016 roku po raz kolejny matce zaoferowano pomoc pedagoga szkolnego w celu zrozumienia choroby syna oraz podjęcia próby jej zaakceptowania, a także wytłumaczenia kobiecie pozytywnych aspektów nieizolowania dziecka od innych rówieśników ze względu na jego stan zdrowotny. Kobieta wykazuje trudną współpracę z pedagogiem szkolnym oraz nauczycielami spowodowane jest to faktem, iż chorobę psychiczną posiadał jej mąż, co skutkowało przykrymi doznaniami jakie kobieta przeżyła. Śmierć męża spowodowała, że kobieta zamknęła się w sobie i stała się nadopiekuńcza w stosunku do swojego syna rekompensując mu $\mathrm{w}$ ten sposób brak ojca. Opieka psychologa szkolnego pomogła kobiecie odnaleźć porozumienie $\mathrm{z}$ nauczycielami oraz przyczyniła się do większego zaangażowania włączenia syna w życie społeczne.

Dziecko z zaburzeniami psychicznymi musi być poddane również odpowiedniej opiece lekarskiej, ale i również pedagogicznej i pielęgniarskiej. Zespół nauczycieli pracujących w szkole z chłopcem sprawował opiekę nad dzieckiem w czasie edukacji oraz współpracował z pielęgniarką szkolną. Współpraca polegała na ustaleniu planu postępowania nad dzieckiem podczas napadu padaczki czy nasilających się stanów agresji lub lęku. Pielęgniarka szkolna udzielała wsparcia nauczycielom z zakresu wiedzy na temat pierwszej pomocy w sytuacjach napadów epilepsji oraz czuwała nad bezpieczeństwem dziecka podczas szkolnych akademii lub uroczystości. Zadaniem pielęgniarki szkolnej była również edukowanie matki na temat zachowania jej syna, sprawowania opieki nad dzieckiem. Pielęgniarka szkolna uświadomiła przede wszystkim matkę, że opieka nad dzieckiem chorym może prowadzić do stanów zmęczenia, bezsilności oraz poczucia, że zasoby emocji osoby opiekującej się chorym członkiem rodziny zostały znacznie uszczuplone. Osoba taka może czuć się zmęczona, cierpieć na bezsenność czy drażliwość oraz bóle głowy. Zadaniem pielęgniarki szkolnej było ukazanie matce sposobów radzenia sobie z przewlekłym stresem, umiejętności korzystania z czasu wolnego dla siebie $\mathrm{w}$ sytuacji kiedy $\mathrm{w}$ domu przebywają nauczyciele sprawujący opiekę nad dzieckiem $\mathrm{w}$ trakcie edukacji. Działania pielęgniarki szkolnej pozwoliły matce $\mathrm{w}$ ciągu tygodnia kiedy dziecko przebywała na zajęciach znaleźć czas wolny dla siebie w celu ustabilizowania swoich emocji oraz napięcia związanego ze stałą opieką nad chłopcem. Kluczową rolę opieki na dzieckiem chorym na zaburzenie psychiczne odegrała współpraca pielęgniarki szkolnej z zespołem nauczycieli. Porady dotyczące zapewnienia spokoju podczas zajęć, unikania sytuacji, które są stresujące dla chłopca ora zwracanie szczególnej uwagi na jego stan emocjonalny oraz psychiczny przyczyniły się do złagodzenia stanów agresji oraz lęków. Działania nauczycieli nastawione były na odpowiednie zorganizowanie zajęć szkolnych, modulowanie głosem, tak aby chłopiec czuł się na zajęciach bezpiecznie, ważnym elementem było aby zajęcia edukacyjne w ciągu roku szkolnego były prowadzone przez tych samych nauczycieli, co zapewniło chłopcu większe poczucie bezpieczeństwa oraz pozwoliło zmniejszyć stany lękowe u chłopca. 
Uczestnictwo chłopca podczas uroczystości szkolnych było dla chłopca oraz jego matki silnym stresem, ponieważ pojawiające się napady epilepsji lub zaburzenia zachowania były nieakceptowane wśród społeczności szkolnej. Zespół nauczycieli i pielęgniarka szkolna zorganizowali dla rodziców $\mathrm{w}$ szkole spotkanie edukacyjne $\mathrm{w}$ celu wyjaśnienia problemu choroby, jej skutków. Duży udział pielęgniarki szkolnej w tym spotkaniu wspomógł nauczycieli, którzy starali się zmienić podejście i świadomość innych rodziców na temat zaburzeń psychicznych u dzieci. Starali się pokazać i uświadomić innych rodziców, iż dzieci chore również pragną być akceptowane $\mathrm{w}$ społeczeństwie, że ważnym elementem jest okazanie wsparcia dzieciom i ich rodzinom, tak żeby nie czuli się osamotnieni ze swoimi problemami. Przeprowadzona rozmowa z rodzicami w szkole był uzgodniona wcześniej z matką chłopca, ponieważ to ona podjęła decyzję o tym, iż chce poinformować również inne osoby o chorobie i wyjaśnić zachowania syna, które wzbudzają u innych dzieci zaskoczenie. Nauczyciele starali się również dostosowywać tok nauczania, możliwości ucznia do jego potrzeb. Pracowali w oparciu o pozytywne wzmocnienia, pochwały, nagradzania tak żeby zniwelować stres udziecka a zwiększyć jego samoocenę. Poszczególni nauczyciele zwiększali również wymagania wobec chłopca jednak z zachowaniem szczególnej ostrożności, aby chłopiec nie czuł się zbyt niepewnie w osiąganiu nowych umiejętności. Ważnym elementem było również wspieranie chłopca, motywowanie go do podejmowania działań. Pielęgniarka szkolna podczas pobytu chłopca w szkole kontrolowała przyjmowanie przez chłopca leki ustalone przez lekarza, a także monitorowała jego zachowania względem innych osób. Poszczególni nauczyciele, jak i pedagog szkolny współpracowali nawzajem obserwując zachowania chłopca w środowisku szkolnym.

Sprawując opiekę nad dzieckiem chorym w szkole należy uwzględnić odpowiednie zapewnienie współpracy między nauczycielami, pielęgniarką szkolną oraz pedagogiem. Poprzez współpracę oraz koordynację zadań możliwe jest zabezpieczenie ucznia przed niepotrzebnym stresem oraz stanami lękowymi.

\section{Dyskusja}

Termin psychoza oznacza poważne zakłócenie funkcji psychicznych na przykład jak: postrzeganie otoczenia i samego siebie, myślenia, oceny rzeczywistości, przeżywania, wyrażania emocji. Osoba, która choruje na psychozę bardzo często zdarza się, ze nie jest w stanie w sposób prawidłowy i adekwatny ocenić, co się dzieje wokół niej, zdarza się bardzo często, iż działa w sposób chaotyczny oraz mało przewidywalny. Psychoza jest zaburzeniem, które wymaga interwencji lekarza, który podejmie odpowiednie leczenie. Najpoważniejszym zaburzeniem przebiegającym z objawami psychozy jest schizofrenia. Schizofrenia jest przewlekłą chorobą o zróżnicowanym obrazie, która dosięga przeważnie młodych ludzi. Należy jednak pamiętać o tym, iż schizofrenię można rozpoznać już w okresie dojrzewania, jak i również u dzieci ,1,2, 3]. Schizofrenia występująca u dzieci charakteryzuje się różnorodnością objawów, tak samo jak i u dorosłych. U dzieci chorych na schizofrenie można zauważyć objawy pozytywne, negatywne, jak i również objawy dezorganizacji psychicznej, zaburzeń funkcji poznawczych, nastroju, jednak ich manifestacja czasami różni się i jest inna niż u dorosłych. Do objawów pozytywnych czyli inaczej wytwórczych - doznań prowadzących do nieprawidłowej lub fałszywej oceny rzeczywistości, możemy tutaj wyróżnić: halucynacje, które powodują, iż dziecko może widzieć przedmioty, sceny, postacie; omamy wzrokowe, głosy, śmiechy które w rzeczywistości nie występują. Rzadziej natomiast mamy do czynienia z omamami węchowym i lub czuciowymi, których przyczyna w rzeczywistości nie występuje. Dziecko, które doznające omamów jest przekonane, że są one prawdziwe i nie potrafi że to, co widzi lub słyszy w rzeczywistości nie występuje. Urojenia fałszywe, które nie mają pokrycia w rzeczywistości, dziecko przeżywa jako 
prawdę i trudno jest mu wytłumaczyć, że rzeczywistość wygląda inaczej. Urojenia stwierdza się już u dzieci od 6-7 roku życia[2,5]. Na początku są one krótkotrwałe, a ich treści są zazwyczaj proste. U starszych jednak dzieci urojenia przyjmują już bardziej złożony, trwały charakter. Najczęściej u dzieci występują urojenia ksobne, wówczas to, dziecko twierdzi, że wszyscy na niego patrzą i o nim rozmawiają. Występują również urojenia prześladowcze, kiedy to dziecko uważa ,iż inne osoby chcą wyrządzić mu krzywdę, śledzą go, podsłuchują. Urojenia hipochondryczne powodują, iż chory uważa że organizm jego nie funkcjonuje w sposób prawidłowy oraz urojenia dysmorfofobiczne, kiedy dziecko ma poczucie, iż jego własne ciało zmienia się lub ulega zniekształceniu [1,5].

U dzieci do szóstego roku życia nie występują urojenia, dlatego gdyż ich procesy myślowe nie są jeszcze dojrzałe. Natomiast można już zaobserwować nieprawidłowości w postaci przeżywania rzeczywistości lub identyfikowanie się z przedmiotami, zwierzętami czy na przykład nieodróżnianie fantazji i snów od rzeczywistości. Dezorganizacja psychiczna, która występuje dotyczy stanu chaosu i rozregulowania funkcji psychicznych. U dziecka można zaobserwować zaburzenia zdolności poznawczych, gdzie dziecko łatwo się rozprasza, występują problemy z przypominaniem sobie na przykład zdarzeń. Dziecko takie napotyka na ogromne problemy w nauce w szkole. Dla schizofrenii dziecięcej często charakterystyczne są: nasilenie lęku, którego nie udaje się ukoić i tak naprawdę nie ma rzeczywistej przyczyny jego powstawania, występują bujne fantazje o dziwnych treściach, nawet przerażających, agresywnych, a także makabrycznych, można zauważyć zaabsorbowanie dziecka jego wewnętrznymi przeżyciami, co powoduje, że nie zwraca uwagi na otaczający go świat $[3,5]$. W schizofrenii dziecięcej niejednokrotnie zdarza się występowanie natręctw. U dzieci schizofrenia rozwija się powoli oraz skrycie. Często u dziecka obserwuje się pogorszenie na przykład wyników w nauce czy niechęć do przebywania wśród rówieśników może wystąpić osłabienie relacji z najbliższymi jak na przykład z matką oraz przygnębienie, apatia. Od okresu pojawienia się pierwszych objawów do chwili rozwinięcia ich pełnego obrazu może minąć nawet do 5 lat. Schizofrenia u dzieci ma przewlekły przebieg, co oznacza że nie pojawiają się okresy bezobjawowe. Przyczyny schizofrenii u dzieci są złożone. Do zachorowania może dojść w wyniku wspólnego działania biologicznych czynników jak zmian zachodzących w budowie anatomicznej mózgu czy nieprawidłowego działania neuroprzekaźników, genetycznych czynników, które zwiększają ryzyko zachorowania w momencie gdy na schizofrenię choruje członek rodziny bądź bliski krewny, a także czynniki psychogenne oraz środowiskowe. U dzieci chorych na schizofrenię ważną rolę odgrywają również czynniki neurorozwojowe czyli nieprawidłowości, które występują w budowie i funkcjonowaniu mózgu. Zaliczamy do nich: cechy nadpobudliwości, słabą koordynację ruchów, opóźniony rozwój mowy i rozwój intelektualny, opóźniony rozwój psychoruchowy już w okresie niemowlęcym, slaby kontakt emocjonalny z dzieckiem[4,2,6]. Schizofrenie u dziecka rozpoznaje się na podstawie zebranego przez lekarza psychiatrę wywiadu zebranego od opiekunów dziecka oraz na podstawie badania psychiatrycznego W przypadku występowania ostrych objawów psychotycznych u dziecka zebranie wywiadu może stać się niemożliwe ze względu na utrudnieniem nawiązania kontaktu logicznego. Lekarz czasami posługuję się również obserwacją zebraną od innych osób jak nauczycieli, wychowawców. U dzieci tak samo jak i u dorosłych stosuje się te same kryteria diagnostyczne. Uzupełnieniem badania psychiatrycznego może być również stosowanie różnych kwestionariuszy i skal oceny nasilenia objawów [4,5,6]. Podstawową metodą leczenia schizofrenii występującej u dzieci jest zastosowanie leków, a także oddziaływań terapeutycznych. Są one ważne w przypadku nasilonych objawów, których nie da się prowadzić bez ustabilizowania stanu psychicznego dziecka za pomocą leków. Ostre, czy nasilone objawy 
często wymagają hospitalizowania szpitalnego. Cel leczenia jest nastawiony na zmniejszenie nasilenia lub braku objawów oraz umożliwienie dziecku w miarę możliwości prawidłowego rozwoju, czy uzyskanie niezależności. Nawet po ustąpieniu objawów dziecko nadal musi kontynuować zażywanie leków w celu utrzymania stabilnego stanu. Dodatkowym uzupełnieniem farmakoterapii u dziecka może być również psychoedukacja dziecka, jego rodziców czy zapewnienie im odpowiednich informacji na temat objawów czy sposobów leczenia choroby, jaki również oddziaływania terapeutyczne, psychoterapię indywidualną, terapię grupową, terapię rodzinną, treningi umiejętności społecznych, terapię zajęciową [1,3, 4]. Należy pamiętać iż choroba zaburza nie tylko funkcjonowanie dziecka, ale i również jego rozwój intelektualny czy emocjonalny i społeczny. Chłopiec w okresie nasilenia stanów leczony jest w szpitalu psychiatrycznym. Zastosowanie odpowiedniej farmakoterapii pozwala na złagodzenie stanów, objawów schizofrenii. Leczenie chłopca nie odbywa się tylko i wyłącznie poprzez farmakoterapię, ale także stosowana jest psychoterapia, socjoterapia oraz rehabilitacja. Dziecko uczestniczy w społeczności terapeutycznej, zastosowane są elementy psychoterapii indywidualnej i grupowej, arteterapia oraz muzykoterapia. Chłopiec znajduję się pod opieką specjalistów z poradni psychologiczno-pedagogicznej, gdzie na podstawie orzeczenia zastosowano indywidualne nauczanie na terenie domu, aby ograniczyć stany napięciowe oraz lękowe u chłopca. Również nauczyciele prowadzący lekcje $\mathrm{z}$ chłopcem na terenie domu, dobierają najkorzystniejsze formy nauczania, tak aby chłopiec mógł uczestniczyć w pełni $\mathrm{w}$ zajęciach edukacyjnych i czerpać $\mathrm{z}$ nich jak największą wiedzę. Matka chłopca korzysta również z pomocy pedagogicznej oraz psychologicznej szkoły. Dzięki odpowiedniemu przekazaniu informacji przez lekarzy, psychologów oraz pedagogów w większym stopniu rozumie zachowania syna. Matka zgadza się na uczestniczenie swojego syna w życiu społecznym oraz nie próbuje już $\mathrm{w}$ tak dużym stopniu izolować go od rówieśników. Praca $\mathrm{z}$ dzieckiem chorym na schizofrenię paranoidalną wymaga dużego zaangażowania ze strony matki, lekarzy oraz pedagogów. Chłopiec oprócz zaburzenia psychicznego choruję również na padaczkę, co stanowi również kolejny problem dotyczący jego stanu zdrowotnego. Padaczka nie jest jednostką chorobową odrębną. W ten sposób określa się tak zespół objawów, który towarzyszy wielu schorzeniem ośrodkowego układu nerwowego. Objawy spowodowane są zazwyczaj nadmiernymi wyładowaniami neuronów oraz nieprawidłowym rozprzestrzenianiem się w mózgu pobudzenia [7,8]. Padaczka cechuję się napadami padaczkowymi, którym zazwyczaj towarzyszą objawy somatyczne, wegetatywne, a także psychiczne. Każdorazowe rozpoznanie padaczki musi być poprzedzone na wnikliwie przeprowadzonym wywiadzie płodowookołoporodowym, dlatego gdyż bardzo istotne jest otrzymanie opisu samego napadu. Należy pamiętać, iż nie można pominąć rozmowy z dzieckiem, które, może dostarczyć wielu ważnych lekarzowi informacji, oczywiście rozmowa z pacjentem jest możliwa wówczas gdy mamy zachowany kontakt słowno-logiczny. W przypadku rozpoznania padaczki stosowane są również dodatkowe badanie takie jak: EEG (elektorencefalografia), CT (tomografia komputerowa), MRI (rezonans magnetyczny), badanie psychologiczne [7,9]. Padaczka należy do chorób przewlekłych, objawami są napady o różnym przebiegu, które występują w różnych momentach i nie można do końca ich przewidzieć. Istnieje jednak szereg czynników, które mogą przyczynić się u niektórych pacjentów do napadów padaczkowych, a zaliczamy do nich: infekcje, niesystematyczne leczenie, intensywne oddychanie, pozbawienie snu, zdenerwowanie. Padaczkę leczy się za pomocą środków farmakologicznych. Zastosowanie leków u dziecka powinno być poprzedzone ustalonym rozpoznaniem padaczki, jego rodzaju. W celu ustalenia przeprowadza się wywiad okołoporodowy, wywiad dotyczący rozwoju psychoruchowego dziecka oraz przebiegu klinicznych napadów. Wykonywane są również badania neurologiczne, 
psychologiczne, a czasami również i psychiatryczne, wykonuje się również i analizuje zapis EEG $[7,8,10]$.

Dzieci chore na schizofrenię i padaczkę w okresie szkolnym są narażone na wykluczenie społeczne, ze względu na odmienność w swoim zachowaniu, niską wiedzę rodziców innych dzieci na temat zaburzeń psychicznych. Dzieci niejednokrotnie chcą być izolowane przez rodziców, co potęguję stany napięcia, lęki dzieci w przyszłości. Rodzice przezywają silny stres związany $\mathrm{z}$ chorobą dziecka [11,12]. Dużą rolę $\mathrm{w}$ rozumieniu zagadnienia zaburzeń psychicznych i uświadomieniu rodziców o problemach ich dzieci stanowią poradnie psychologiczno-pedagogiczne oraz psycholog lub pedagog szkolny, a także nauczyciele współpracujący z dziećmi. Najważniejszą rolę odgrywać powinna edukacja społeczeństwa poprzez akcje społeczne, kampanie, które będą uświadamiać społeczeństwo o zaburzeniach psychicznych wśród dzieci, umiejętności radzenia sobie ze stresem, a także przełamywaniu barier izolacji społecznej. Ważną kwestię odgrywa również współpraca między pielęgniarką szkolną, nauczycielami, pedagogiem, a rodzicami dziecka chorego na zaburzania psychiczne. Odpowiednia koordynacja zadań pomiędzy tymi osobami pozwali zapewnić dziecku jak najlepszą opiekę podczas edukacji szkolnej.

\section{Wnioski}

Schizofrenia paranoidalna, na którą chorują również dzieci jest zagadnieniem szeroko opisywanym w literaturze fachowej. Opisane zostały nie tylko objawy, częstotliwość występowania choroby w okresie dziecięcym, ale i również wskazówki dotyczące radzenia sobie z dzieckiem chorym na zaburzenie psychiczne dla rodziców i nauczycieli. Leczenie dzieci z zaburzeniami odbywa się nie tylko za pomocą farmakoterapii, alei również za pomocą metod terapeutycznych $[11,13,14]$. Ważną rolę odgrywa edukacja rodziców na temat schorzenia ich dzieci, umiejętność radzenia sobie z nasileniami choroby, jak i również umiejętność radzenia sobie z dzieckiem, jego edukacją i funkcjonowaniem w życiu społecznym. Dzieci z zaburzeniami psychicznymi stanowią duże wyzwanie nie tylko dla lekarzy, ale i również dla nauczycieli. Przekazywanie informacji, które pozwolą przezwyciężyć rodzicom stres, jaki napotykają w związku z chorobą swoich dzieci nie należą tylko do kompetencji lekarzy, ale w dużym stopniu do nauczycieli $[4,5,10]$.

Dzieciom $\mathrm{z}$ zaburzeniami psychicznymi bardzo trudno odnaleźć jest się w społeczeństwie. Szkoły podejmują działania mające na celu niwelowanie barier, jednak nadal w małych miejscowościach występuję brak zrozumienia i tolerancji nie tylko ze strony dzieci, ale i również rodziców tych dzieci. Kluczową rolę powinna odgrywać edukacja, która zapewni większe zrozumienie problemu zaburzeń psychicznych wśród dzieci.

\section{Bibliografia/Bibliography:}

1. Kępiński A. Schizofrenia. Wydawnictwo Literackie, Kraków 2001: 15-32.

2. Namysłowska J. Psychiatria dzieci i młodzieży. Wyd. Lekarskie PZWL. Warszawa 2004: 211-345.

3. Bodura-Madej W., Bratnik E.Psychiatria dzieci i młodzieży. Wyd. Lekarskie PZWL. Warszawa 2012: 220-300. 
4. Namyslowska J. Dziecko z zaburzeniami psychotycznymi w szkole. ORE. Warszawa 2010: 10-19.

5. Namysłowska I. Kontakt terapeutyczny $\mathrm{z}$ osobą chorą na schizofrenię. Postępy Psychiatrii i Neurologii 2006; 15(3): 136-140.

6. Obrębska M. Styl mówienia w schizofrenii. Wydawnictwo Naukowe UAM, Poznań 2013: 34-45.

7. Dunia-Wąsowicz D. Padaczka i inne zaburzenia napadowe u dzieci. Medical Tribune. Warszawa 2013: 86-110.

8. Jędrzejczak J. Padaczka. Wydawnictwo Czelej. Lublin, 2006: 12-20.

9. Jędrzejczak J. I Ty możesz zachorować na padaczkę. TacyJakJa.pl. 2012:34-50.

10. Steinborn B. Leczenie padaczki u dzieci i młodzieży. TERMEDIA. Poznań 2011:101-131.

11. Ciałkowska-Każmińska N. Potrzeby osób z zaburzeniami psychicznymi, a obciążenia opiekunów. Akademia Medyczna. Wrocław 2011.

12. Werz Mary Ann, Pita Ignacio L. Zespoły padaczkowe. Urban \&Partner. Wrocław 2013: 23-37.

13. Anczewska M., Roszczyńska-Michta J. 0 umacnianiu pacjentów w procesie zdrowienia. Instytut Psychiatrii i Neurologii. Warszawa 2007: 67-81. 